\title{
THE EFFECT OF GOVERNMENT EMPLOYMENT ON INCOME INEQUALITY OVERALL AND IN THE SOUTH: EVIDENCE FROM CONGRESSIONAL DISTRICT DATA
}

\author{
Natalie Brem, Garey Durden and Patricia Gaynor*
}

\section{Introduction}

Several studies have sought to determine empirically the factors that cause income to be distributed unequally across regions. These studies, (for example, Conlisk, 1967; Danziger, 1976; Aigner and Heins, 1967; Hirsch, 1978; Hirsch, Seaks and Formby, 1980; Durden and Schwarz-Miller, 1982) employ data from states, SMSAs or congressional districts and concentrate mainly on determining how regional income inequality is affected by levels of economic development and human capital, and by discrimination against women and blacks. The general consensus is that inequality decreases as human capital and economic development increase, ${ }^{1}$ and increases with the relative number of women and blacks in the work-force, implying that discrimination is a factor. ${ }^{2}$ Effective government programs might thus: (1) foster economic growth and development; (2) provide or guarantee educational opportunities and other human-capital enhancing programs for minorities and for the poor, and; (3) reduce economic discrimination against minority groups and women.

While several studies have looked at the relationship between government employment and black-white relative employment, income or wage levels (Long, 1975; S. Smith, 1976a, 1976b; Quinn, 1979; Fogel and Lewin, 1974; Baker and Colby, 1981; Borjas, 1982; Buckele, 1982; Cayer and Sigelman, 1980) very little work has been done on the relationship between income inequality and levels of government employment. Two exceptions are Conlisk (1967) and Durden and Schwarz-Miller (1982).

The major purpose of this paper is to test the hypothesis that government employment and family income inequality are inversely related. A secondary purpose is to determine whether influences discovered in earlier studies retain their power to explain inequality. Unlike most previous wor, $\mathrm{k}$ but following Farbman (1973), the data for the empirical tests reported were were stratified into southern and non-southern regions. In Section II the literature on the effects of the public-sector on the employment and earnings of minorities and women relative to white males is discussed.. These studies generally conclude that federal and state government employment narrows the pay differ-

*Graduate student and professors of economics, Appalachian State University, Boone, North Carolina entials between white males and minorities and women. The employment opportunities of the latter two groupsalso appear positively affected. By inference, it would be expected, ceteris paribus, that an increase in the number of federal and state government workers would mean less discrimination, less low-income employment and, consequently, greater equality in family incomes. In Section III the model and proxy variables are presented, presentation of the empirical results follows in Section IV, and the summary and conclusions are outlined in Section V.

\section{Impact of the Public-Sector on Employment and Income}

D.A. Smith (1980), estimated the impact of government employment on relative black/white wages and examined relative pay and hiring practices in the government sector. Using data from the May 1975 Current Population Survey, Smith found that comparable people in public and private employments are not paid equally, with blacks faring better in government jobs. The pay difference varied significantly according to the sub-sector (federal, state, or local) studied. Smith discovered that, for both males and females, blacks are proportionately over represented at all levels of government, with the exception of males in state government. Government sector wage and hiring policies raised the relative wages of black workers by about 2 percent.

Borjas (1982) focused on the pay of minority and femal workers in various federal government agencies. His analysis was based on a "Public Choice" view of government behavior ...that government has a single objective, the maximization of political support. He designated this the 'vote-maximization hypothesis.' Borjas hypothesized that the economic status of minorities in a federal government agency depended upon their importance to the political support of the agency. He used the number of minority constituents of a federal agency as a proxy for the political support the agency might expect to receive.

The empirical evidence collected by Borjas indicated that the wages of blacks and women varied widely relative to wages of white males across the federal government agencies. He found that wages for black males were higher relative to those of white males when the agency has a large number of minority constituents. His evidence 
indicated that the relative wage of women depended upon the number of women constituents. He concluded that southern states should be considered separately, due to the large number of black constituents.

Baker and Colby (1981) offered support for the analysis of Borjas. They found that larger black populations are associated with higher black public employment levels. Their study offers justification for looking separately at the southern states which typically have large black populations.

Cayer and Sigelman (1980) analyzed the employment of minorities and women in state and local govemments across the country. They were concerned with the effect of the Equal Employment Act of 1972 on the employment status of women. Cayer and Sigelman found that between 1973 and 1975 white women and black men and women made significant gains in state and local government employment but still were far behind white males in job status and pay. Women actually lost ground between 1973 and 1975. Employment gains by minorities and women at state and local government levels resulted from creation of more than 90,000 new jobs in local and state government. The authors believed that much of this gain could be attributed to the Equal Employment act of 1972.

Long (1975) offered an empirical foundation for the hypothesis that the government is less discriminatory than non-government employees, and therefore lessens income inequality. Long focused on the sectorial differences in employment opportunities for blacks relative to those for whites. His analysis of the data revealed that employment opportunities for blacks are significantly more favorable in the public than in the private sector. In a related study, Long (1980) showed that public sector workers, receive economic rents. Studies by Perloff (1971), Fogel and Lewin (1974) and Field and Keller (1976) suggest that federal and local government employment results in higher incomes for low income workers, and lower incomes for those in the upper income quintiles. These results reinforce the notion that government employment has an equalizing effect on the distribution of family incomes.

Quinn (1979) and Sharon Smith (1976a) showed that government workers receive better pay than private sector workers for comparable jobs. Quinn employed a human capital model of wage determination to compare wages in federal, state, and local public administration jobs with those in the private sector. After adjusting for personal and geographic differences, he found that federal and state government employees were paid more than private sector employees in comparable jobs. He also found that public sector employees enjoyed more fringe benefits, greater job stability, and a more attractive work environ- ment than private sector employees.

Surprisingly, Quinn found that local government employees were paid less than equivalent private sector workers, but noted that this was offset by the better fringe benefits, job stability and superior work environment for local government workers. Smith suggested that in the 1960 s, when the federal government adopted a policy to ensure that the pay of federal government worker was comparable to a private sector worker, it went too far. The result was that government workers earn economic rents, a conclusion supported by Long (1980). She used a human capital model to decompose the pay differentials and found that in both 1960 and 1970 federal workers were paid more than comparable private sector workers. ${ }^{3}$

Buckele (1982) and Milne (1980) offer additional empirical evidence for focusing on the southern states in a study of income inequality. Buckele found that 51.2 percent of southern blacks lived in urban areas in 1980. Milne found that migration to southern SMSA benefits blacks more than it does whites because the black-white earnings differential is less in urban than in rural areas in the south.

Durden and Schwarz-Miller (1982) tested the relationship between inequality and public-sector employment. They used the same independent variables as Conlisk (1967) and Danziger (1976), but added the percentage of workers employed by federal, state and local governments. Their results suggested that all three types of government employment are inversely related to income inequality. Durden and Schwarz-Miller tested ithe inequality relationships using data from all 435 Congressional districts. As is shown in this report, stratification of the data into southern and non-southern componenets produces results very different from those attained by Durden and Schwarz-Miller.

Empirical tests for the determinants of regional income inequality were based on the expression

$$
y=a_{1} H+a_{2} D I+a_{3} E D+a_{4} G+a_{5} 0+e
$$

where: $y$ is the inequality measure, H, DI, ED and G are vectors of human capital, discrimination, economic development and government influence proxies. The vector 0 measures "other" influences, the $\mathrm{a}_{1}$ terms are parameter estimates and $e$ is the error term. The data were observations from the 435 congressional districts of the United States taken from the Congressional District Data Book (1984) for the 1980 census. Following many earlier studies, the Gini ratio, created from the family income information in the Data Book, was employed as the inequality measure. 


\section{Public Sector Variables}

Three variables were included to measure the impact of public sector employment on income inequality: these were FEDERAL, STATE, and LOCAL, the percentages of workers employed in federal, state, and local government jobs. Based on the results of the public employment studies discussed above, it was expected that as FEDERAL, STATE, and LOCAL were increased, the level of family income inequality would decrease.

Shooling, Discrimination and Economic Development Proxies

The set of proxy independent variables (other than those for public-sector influences) generally used for testing the relationships between inequality and its determinants is discussed in detail in earlier works. A brief discussion is required here, primarily because of the difference between the results of this study and the results of others which have used schooling measures as independent variables. Most studies have used median years of education and have found a negative relationship (Aigner and Heins, 1967; Farbman, 1975; Sale, 1974) between the level of schooling income and inequality. Studies that have modeled and tested the relationship between inequality and schooling (Chiswick, 1974; Hirsch, 1978) have shown that earnings inequality is related positively to the distribution of education, to the rate of return to education and to the level of education. Thus, inequality studies that have considered only a median or average level of education may have produced misleading results. The median or average education variable may have picked up the otherwise unmeasured influences of a more equal distribution of education.

Following Hirsch et al. (1980) this study included the median education level in each congressional district and proxy measures for the dispersion of schooling across districts. These included ELEMENTARY, the percentage of the work-force with eight or fewer years of education and COLLEGE, the percentage having four or more years of college. These variables should have positive signs. Median education level (MEDED) then should, ceteris paribus, pick up the influence of the rate of return to schooling and exhibita positive relationship to the inequality level.

Discrimination influences generally are proxied by including the percentage of blacks and females in the population or labor force or by the percentages of black and female-headed families (Durden and Schwarz-Miller, 1982; Hirsch, et al. , 1980; Danziger, 1976). Since this study tested for the determinants of family inequality, variables for black (BLACKFAM) and female (FEMHEAD) heads of families were used and their coefficients were expected to be negative.

The level of median family income (MEDINC) and the percentage of population living in urban areas (URBAN) were used as indicators of economic development and were expected to be related negatively to inequality of income. Some measure of relative income has been used in virtually all regional inequality studies. Several studies also have looked at effects of urbanization or city size on inequality (Long, Rasmussen and Haworth, 1977; Garofolo and Fogarty, 1979; Danziger, 1976; Slottje and Hayes, 1987) and generally have found a negative relationship. Most studies have also used one or more measures to capture industrial structure differences. Manufacturing employment as a percentage of the total employed labor force (MANUFACT) is one of the more popular proxies and it is employed here.

\section{Other Variables}

Two other nonpublic sector proxies were employed, a wealth variable and an age measure. The median value of housing in each congressional district (WEALTH) was used as a measure of wealth. Since wealth is very unequally distributed, this variable should be positively associated with income inequality. The aged variable (OLDER) was the percentage of the total population 65 years old and older. Increases in this variable have been associated with inequality increases in most previous studies and a positive relationship was expected here.

Early regression models also included unemployment, relative population size and percentage of the work force in white collar employment (Hirsch et al. 1980) but these added nothing to explanatory power, perhaps due to multicollinearity between these and other variables. In addition, the labor force variables used here were computed as percentages of the employed labor force, and this probably captures some of the influence generally accorded the unemployment rate. Mean values for the variables used in the south and non-south regressions are presented in Table 1.

\section{Empirical Results}

For the empirical analysis, all 435 congressional districts were used in the initial regressions; the data then were stratified into southern ${ }^{4}$ and non-southern components. ${ }^{5}$ The results are shown in Table 2 . In each case, two versions were estimated, one with FEMHEAD and BLACKFAM included, one with BLACKFAM excluded. Multicollinearity precluded using both variables in the 
The Effect of Government Employment On Income Inequality Overall

and in the South: Evidence From Congressional District Data

Table 1

Mean Values of Variables Used in the South and Non-South Regressions

\begin{tabular}{|c|c|c|c|c|}
\hline \multirow[t]{2}{*}{ Variables } & \multicolumn{2}{|c|}{ South } & \multicolumn{2}{|c|}{ Non-South } \\
\hline & Mean & S.D." & Mean & S.D. \\
\hline COLLEGE & 14.3 & 5.9 & 16.5 & 6.3 \\
\hline FEDERAL & 5.1 & 4.5 & 3.4 & 1.8 \\
\hline BLACKFAM & 17.8 & 13.3 & 8.1 & 13.9 \\
\hline FEMHEAD & 14.7 & 4.2 & 13.7 & 6.2 \\
\hline STATE & 5.7 & 3.1 & 4.3 & 2.6 \\
\hline ELEM & 23.4 & 7.6 & 16.6 & 6.3 \\
\hline OLDER & 25.9 & 8.2 & 26.0 & 7.0 \\
\hline URBAN & 63.7 & 24.0 & 76.6 & 21.4 \\
\hline MANUFACT & 18.7 & 8.4 & 21.1 & 7.3 \\
\hline MEDED & 12.3 & 3.2 & 12.5 & 2.8 \\
\hline GINI & 40.4 & 2.4 & 38.9 & 3.0 \\
\hline MEDINC & 15201.0 & 3204.0 & 17696.0 & 3611.0 \\
\hline WEALTH & 426.0 & 142.4 & 531.3 & 232.7 \\
\hline LOCAL & 8.3 & 1.3 & 8.8 & 1.9 \\
\hline $\mathrm{N}$ & \multicolumn{2}{|c|}{104} & \multicolumn{2}{|c|}{331} \\
\hline
\end{tabular}

aS.D. is the standard deviation.

same equation. ${ }^{6}$ For ease of analysis, the variables in Table 2 were grouped according to the influences they were intended to proxy. The human capital and schooling variables, MEDED, ELEMENTARY and COLLEGE were highly significant in all regressions. ELEMENTARY and COLLEGE had the expected sign in all cases. The positive sign on the MEDED variable differed from the findings of most studies but was consistent with Hirsch, Seaks and Formby (1980). The results were that, when the dispersion of educational attainment was considered, increased levels of schooling increased income inequality.?

The discrimination proxies, FEMHEAD and BLACKFAM were highly collinear so that measurement of their individual effects was not possible. When they were included together, FEMHEAD consistently was insignificant; when the FEMHEAD variable was entered singly, it was highly significant and had the correct sign. ${ }^{8}$ A larger percentage of families headed by blacks or females still is apparently associated with a greater degree of income inequality than is found in other families.

The OLDER and WEALTH variables were significant and had the expected signs in the overall and nonsouth regressions but were, insignificant in those for the south.

The development variables, MEDINC, MANUFACT and URBAN had the correct signs in all cases except one. The former two always were highly significant while URBAN was significant only in the non-south regressions.
While generalization about the URBAN variable isnot well-supported, the results suggest that a greater degree of urbanization reduces income inequality only in non-southern congressional districts. The null hypothesis could not be rejected elsewhere.

The variables of primary interest in this study were the government employment measures, FEDERAL, STATE, and LOCAL. In the overall regressions, the results were similar to those found by Durden and Schwarz-Miller (1982). Larger percentages of government employment appeared to reduce income inequality, with FEDERAL employment highly significant and STATE significant at the 5 percent level or greater. When the data were stratified geographically, however, a different result was obtained.

In the non-south regressions, none of the government variables was significant, though all had negative signs. Thus, the null hypothesis could not be rejected, suggesting that government employment added nothing to the explanation of income inequality differentials in congressional districts outside the south.

In the south regressions, federal and state employment had negative signs and were significant at above the 1 percent level of confidence. The LOCAL variable had a positive signs and was significant at the 5 percent level. Taken together, these results indicate that, in the south, federal and state employment had strong income equalizing effects, while inequality increased with local govern- 
Table 2

Determinants of Family Income Inequality Overall and in Two Subregions

\begin{tabular}{|c|c|c|c|c|c|c|}
\hline \multirow[t]{2}{*}{ Variables } & \multicolumn{2}{|c|}{ Overall } & \multicolumn{2}{|c|}{ Non-South } & \multicolumn{2}{|c|}{ South } \\
\hline & $(1)^{2}$ & (2) & (1) & (2) & (1) & (2) \\
\hline \multirow[t]{2}{*}{ MEDED } & .5545 & .5326 & .5336 & .5404 & .7945 & .7764 \\
\hline & $(5.16)$ & $(4.83)$ & $(4.27)$ & $(4.28)$ & (3.79) & $(3.66)$ \\
\hline \multirow[t]{2}{*}{ ELEMENTARY } & .0271 & .0268 & .0282 & .0279 & .0320 & .0300 \\
\hline & $(6.07)$ & (7.76) & $(6.92)$ & (6.79) & (5.63) & (5.31) \\
\hline \multirow[t]{2}{*}{ COLLEGE } & .0182 & .0178 & .0175 & .0166 & .0210 & .0203 \\
\hline & $(6.06)$ & (5.77) & $(5.23)$ & $(4.93)$ & $(2.93)$ & (2.81) \\
\hline \multirow[t]{2}{*}{ FEMHEAD } & $-.0121^{*}$ & .1275 & $.0543^{*}$ & .1521 & $.0432^{*}$ & .1544 \\
\hline & $(0.31)$ & $(4.62)$ & $(1.14)$ & $(4.70)$ & $(0.55)$ & (3.12) \\
\hline \multirow[t]{2}{*}{ BLACKFAM } & .0571 & - & .0414 & - & .0363 & - \\
\hline & $(4.91)$ & - & $(2.77)$ & - & $(1.80)$ & - \\
\hline \multirow[t]{2}{*}{ OLDER } & .0490 & .0413 & .0846 & .0842 & $-.0106^{*}$ & $-.0149 *$ \\
\hline & (3.10) & $(2.56)$ & $(4.02)$ & $(3.96)$ & $(0.55)$ & $(0.78)$ \\
\hline \multirow{2}{*}{ WEALTH } & .0034 & .0029 & .0038 & .0033 & $.0009^{*}$ & $.0010^{*}$ \\
\hline & $(6.14)$ & $(5.22)$ & (5.73) & $(5.18)$ & $(0.85)$ & $(0.87)$ \\
\hline \multirow[t]{2}{*}{ MEDINC } & -.0005 & -.0104 & -.0003 & -.0003 & -.0008 & -.0008 \\
\hline & $(8.98)$ & $(8.02)$ & $(4.36)$ & $(3.76)$ & (7.79) & (7.71) \\
\hline \multirow[t]{2}{*}{ MANUFACT } & -.0590 & -.0712 & -.0659 & -.0768 & -.0500 & -.0508 \\
\hline & $(3.75)$ & $(4.46)$ & $(2.94)$ & $(3.76)$ & $(2.90)$ & (2.91) \\
\hline \multirow[t]{2}{*}{ URBAN } & $-.0002 *$ & $-.0 .0011^{*}$ & -.0016 & -.0021 & $.0003^{*}$ & $-.0004^{*}$ \\
\hline & $(0.30)$ & (1.52) & $(1.76)$ & $(2.41)$ & $(0.22)$ & $(0.32)$ \\
\hline \multirow{2}{*}{ FEDERAL } & -.1683 & -.1565 & $-.0087^{*}$ & $-.0804^{*}$ & -.1924 & -.1854 \\
\hline & $(4.85)$ & $(4.41)$ & (1.23) & (1.10) & (4.29) & $(4.10)$ \\
\hline \multirow[t]{2}{*}{ STATE } & -.0712 & -.0765 & $-.0474 *$ & $-.0068 *$ & -.1786 & -.1746 \\
\hline & $(1.92)$ & $(2.01)$ & $(0.98)$ & $(1.38)$ & $(3.58)$ & (3.46) \\
\hline \multirow[t]{2}{*}{ LOCAL } & $-.0238^{*}$ & $-.0395^{*}$ & $-.0732 *$ & $-.0765^{*}$ & .2507 & .2518 \\
\hline & $(0.38)$ & $(0.65)$ & (1.04) & (1.08) & (1.95) & (1.92) \\
\hline F VALUE & 62.14 & 61.94 & 45.26 & 47.39 & 26.72 & 27.99 \\
\hline R SQUARED & .65 & .63 & .64 & .63 & .76 & .76 \\
\hline $\mathrm{N}$ & 435 & & 331 & & 104 & \\
\hline
\end{tabular}

"Version (1) of the model included both the FEMHEAD and BLACKFAM variables, version (2) omitted the BLACKFAM variable.

Note: An asterisk indicates a statistically insignificant result. All others are significant at a 5 percent or greater level of confidence.

ment employment levels. The latter finding supports the Quinn (1979) conclusion that local government workers are paid less than their equivalents in the private sector.

\section{Summary and Conclusions}

The analysis and empirical tests conducted for this study support several conclusions of interest to those concerned with the effects of selected socio-economic characteristics on interregional levels of income inequality. First, when measures of schooling dispersion are included in the estimating equations, the median level if education and income inequality are positively related. Second, proxy variables for discrimination exhibit considerable explanatory power with respect to family income inequality. The same is true of proxies for economic development. These findings indicate that efforts to reduce discrimination and promote development will continue to have interregional equalizing effects on family incomes.

The proxy measures for government influence shed new light on the relationship between family income inequality and government employment levels. The litera- 
Table 3

Simple Order Correlation Coefficients for the Independent Variables

Variable

(1) (2)

(3)

(4)

(5)

(6)

(7)

(8)

(9)

(10)

(11)

(12)

South Regressions

\section{COLLEGE}

FEDERAL

$\begin{array}{lll}\text { BLACKFAM } & -.05 & .10\end{array}$

$\begin{array}{llll}\text { FEMHEAD } & -.01 & .08 & .87\end{array}$

$\begin{array}{llll}\text { STATE } & -.13 & -.14 & .25\end{array}$

ELEM

$\begin{array}{ll}-.76 & -.44\end{array}$

OLDER

$-.41 \quad-.29$

$.03 \quad-.01$

$.56 \quad .29$

$\begin{array}{ll}-.02 & -.01\end{array}$

.23

URBAN

MANUFACT

MEDED

$-. .42 \quad-.31$

.21

$-.02$

$\begin{array}{ll}.39 & -.39\end{array}$

.39

$.90 \quad .53$

$-.10$

$-.08 \quad-.06$
-.04

$-.74$

$-.35$

MEDINC

WEALTH

$.81 \quad .61$

$-.25$

$-.04 \quad-.21$

.49

$.08 \quad-.48$

$-.25 \quad-.29$

$-.93$

$\begin{array}{ll}-.40 & .70\end{array}$

$\begin{array}{ll}-.69 & -.53\end{array}$

$.44-.34$

$\begin{array}{llll}-.43 & -.33 & .31 & -.20\end{array}$

.77

$\begin{array}{lllll}.50 & .21 & -.26 & -.24 & -.20\end{array}$

$\begin{array}{lllllllll}.40 & -.02 & -.08 & .29 & .21 & -.27 & .03 & -.17 & -.07\end{array}$

$\begin{array}{lllllllll}.40 & -.02 & -.08 & .29 & .21 & -.27 & .03 & -.17 & -.07\end{array}$

$.50 \quad .62$

Non-South Regressions

COLLEGE

FEDERAL

BLACKFAM $\quad-.18 \quad .23$

$\begin{array}{lll}\text { FEMHEAD } & -.16 & .26\end{array}$

STATE

ELEM

OLDER

$.01 \quad .30$

.84

$-.62 \quad .03$

$-.10$

$-.44 \quad-.01$

.27

$-.09$

$\begin{array}{ll}.36 & -.03\end{array}$

URBAN

MANUFACT

$.33 \quad .15$

.09

$.13 \quad .03$

$\begin{array}{lll}.38 & .51 & -.32\end{array}$

.53

$\begin{array}{lll}-.21 & -.53 & -.01\end{array}$

$\begin{array}{ll}-.01 & -.39\end{array}$

$-.16$

.04

$-.34$

MEDED

MEDINC

$\begin{array}{ll}.83 & -.01\end{array}$

$-.30$

$\begin{array}{ll}-.33 & -.33\end{array}$

$-.86$

$-.06$

$-.06$

$\begin{array}{lll}.57 & -.27 & -.31\end{array}$

$\begin{array}{ll}-.41 & -.24\end{array}$

$-.69$

$-.51$

.24

$-.22$

WEALTH

$.53 \quad .03$

$-.11$

$-.19$

$-.37$

$-.64$

.29

$-.32$

.41

.21

.65

$.42 \quad .01$

$.30 \quad .32$

.03

$-.11 \quad .59$

$.28 \quad .210 .42 .01$

ture, discussed in Section II, suggests that government employment generally is less discriminatory and that the range of earnings there is narrower than in the private sector. Both conditions should contribute to decreased inequality of incomes. But the results also indicate that the apparently ameliorative results observed in the overall regressions may be illusory, masking important differences between geographic sub-regions of the economy. Specifically, the negative and significant relationship between family income inequality and levels of federal and state government employment may hold only for the south; further, as local government employment increases in the south, so does income inequality.

As a reviewer has correctly pointed out, the theoretical relationships between government employment and income inequality are not well modeled, either in this paper or elsewhere in the literature. This is an area of analysis that the authors may pursue later and encourage others to investigate.

\section{Notes}

${ }^{1}$ One notable exception is the finding of Hirsch, Seaks and Formby (1980) that, when differences in the distribution of education are considered, the relationship between inequality and education level is positive. The empirical results of this study support that conclusion.

${ }^{2}$ Some studies, including this one, imply that discrimination variables capture a residual influence not accounted for by measures of productivity differences. The discrimination vari- 
ables also may pick up unmeasured influences such as occupational choice decisions and, decisions to work part-time. By the same token, productivity measures may mask the effects of prior discrimination on choices of career paths and accumulation of human capital.

${ }^{3}$ Smith decomposed the pay differential into explained and unexplained portions. The percentage federal/private pay differential can be decomposed into a portion attributable to discrimination by comparing the actual pay of federal workers with the pay they would have received if both federal and private workers were paid according to the same wage-rate structure.

${ }^{4}$ The south included West Virginia, Virginia, Tennessee, South Carolina, North Carolina, Mississippi, Louisiana, Kentucky, Georgia, Florida, Arkansas, and Alabama.

${ }^{5} \mathrm{~A}$ Chow test to determine whether the south differed from the non-south with respect to parameter estimates was performed and yielded an F-value of 4.212 , significant at the 99 percent level of confidence.

${ }^{6}$ Simple order correlations for the south and non-south regressions are included in Table 3.

${ }^{7}$ However, as the simple order correlations of Table 3 show, there was considerable multicollinearity between MEDED and the two schooling measures, ELEMENTARY and COLLEGE. These results, though correctly reflecting the expectations derived from human capital theroy, must be interpreted with caution.

${ }^{8}$ When BLACKFAM was entered with FEMHEAD omitted, the explanatory power of the equation improved from, for example, 0.64 to 0.67 in the overall results. In the south regressions the statistical significance of the BLACKFAM variable increased to the 1 percent confidence level.

\section{References}

Aigner, D.J., \& Heins, A.J. (1967, March). Determinants of Income Inequality. American Economic Review, 57, 17584.

Baker, D.G., \& Colby, D.C. (1981, July). The politics of Municipal Employment Policy: A Comparative Study of U.S. Cities. American Journal of Economics and Sociology, 40, 249-63.

Borjas, G.J. (1982, October). The Politics of Employment Discrimination in the Federal Bureaucracy. Journal of Law and Economics, 25, 271-99.

Buckele, R. (1982, July/August). The Persistence of Racial Inequality. Challenge, 25, 57-63.

Cayer, N.J., \& Sigelman, L. (1980, September/October). Minorities and Women in State and Local Government: 1973-1975. Public Administration Review, 40, 443-50.

Chiswick, B.R. (1974). Income Inequality: Regional Analysis Within a Human Capital Framework. New York: National Bureau of Economic Research.
Conlisk, J. (1967, February). Some Cross-State Evidence on Income Inequality. Review of Economics and Statistics, 49, 115-18.

Danziger, S. (1976, November). Determinants of the Level Distribution of Family Income in Metropolitan Areas, 1969. Land Economics, 52, 467-78.

Durden, G.C. and Schwarz-Miller, A.V. (1982, March). The Distribution of Individual Income in the U.S. and Public Sector Employment. Social Science Quarterly, 63, 39-47.

Farbman, M. (1973). Income Concentration in the Southern United States. Review of Economics and Statistics, 55, 33040.

Farbman, M. (1975, June). The Size Distribution of Family Income in U.S. SMSAs, 1969. Review of Income and Wealth, 217-37.

Field, C. and Keller, R. (1976). How Salaries of Large Cities Compare with Industry and Federal Pay. Monthly Labor Review, 79, 23-28.

Fogel, D. and Lewin, D. (1974). Wage Determination in the Public Sector, 27, 410-3_G1.

Garofolo, G. and Fogarty, M.S. (1979). Urban Income Distribution and the Urban Hierarchy-Equality Hypothesis. Review of Economics and Statistics, 381-88.

Hirsch, B. (1978, July). Earnings Inequality Across Labor Markets: A Test of the Human Capital Model. Southern Economic Journal, 45, 32-45.

Hirsch, B., Seaks, T. and Formby, J. (1980). Inter-Age and IntraAge IncomeInequality: A Cross-Sectional Analysis. Southem Economic Journal, 1187-1196.

Long, J.E. (1975, June). Public-Private Sectoral Differences in Employment Discrimination. Southern Economic Journal, 42, 89-96.

Long, J. (1980). Are Government Workers Overpaid? Alternative Evidence. Journal of Human Resources, 17, 123-31.

Long, J., Rasmussen, D. and Haworth, C. (1977). Income Inequality and City Size. Review of Economics and Statistics, 244-46.

Milne, D. (1980, January). Migration and Income Opportunities for Blacks in the South. Southern Economic Joumal, 46, 913-17.

Perloff, S.H. (1971). Comparing Municipal Salaries with Industry and Private Pay. Monthly Labor Review, 94, 46-50.

Quinn, J.F. (1979, Winter). Wage Differentials Among Older Workers in the Public and Private Sectors Journal of Human Resources, 14, 41-62.

Sale, T. (1974). Interstate Analysis of the Size Distribution of Family Income. Southern Economic Journal, 40, 434-44.

Slottje, D.J. and Hayes, K.J. (1987). Income Inequality and Urban/Rural Migration. Review of Regional Studies, 53-56.

Smith, D.M. (1980, Winter). Government Employment and Black/White Relative Wages. Journal of Human Resources, $15,77-86$. 
The Effect of Government Employment On Income Inequality Overall and in the South: Evidence From Congressional District Data

Smith, S. (1976a, January). Pay Differentials Between Federal Government and Private Sector Workers. Industrial and Labor Relations Review, 29, 179-97.

Smith, S. (1976b). Government Wage Differentials by Sex. Journal of Human Resources, 11, 185-99.
U.S. Department of Commerce and Bureau of the Census (1984). 1980 Congressional District Data Book (Publication No. PHC80-4). Washington, DC: U.S. Government Printing Office. 